\section{Developing a Water-stress Index for Potted Poinsettia Production}

\author{
Lloyd L. Nackley \\ Horticulture Department, Oregon State University, North Willamette \\ Research and Extension Center, Aurora, OR 97002
}

Elias Fernandes de Sousa

Agricultural Engineering Laboratory, North Fluminense State University, Campos dos Goytacazes, Brazil

\section{Bruno J.L. Pitton, Jared Sisneroz, and Lorence R. Oki \\ Department of Plant Sciences MS6, University of California, Davis, CA 95616}

Additional index words. deficit irrigation, drought, floriculture, ornamental, physiology, sap flux

\begin{abstract}
Potted poinsettia (Euphorbia pulcherrima) is an important commercial commodity for the U.S. floriculture industry. The production of poinsettia demands intensively managed light control, heat, fertilizer, and water; inhibiting elongation with plant growth regulators, and protecting plants from diseases and pests with pesticide applications. Excessive irrigation creates pollution, promotes disease, and is expensive. Sensor-based control systems can optimize irrigation schedules. Irrigation management is crucial in nursery production of poinsettias because water is a limited resource and agricultural runoff is monitored in many states across the United States. By pairing environmental sensors with sensors that continuously monitor plant transpiration, we can determine how plant water use and water stress fluctuate with environmental and physiological demands. We hypothesized that continual measurements of sap flow could be correlated with environmental sensors to develop a new water stress index (WSI), which can deliver the benefits of detecting water stress that might affect the quality of potted poinsettias. To test this hypothesis, rooted cuttings of poinsettia (E. pulcherrima cv. Prestige Red) were individually potted into twelve 11-L black plastic nursery pots. Potted plants were grown in a naturally illuminated temperature-controlled glasshouse. The 12 plants were randomly assigned one of three watering treatments: weekly, biweekly, and triweekly irrigation. From the data collected, we were able to create a WSI that correlated available soil moisture with the difference between the expected transpiration with actual transpiration rates. Our results suggest that the plants in the weekly treatment group did not experience water stress until $0.3 \mathrm{~m}^{3} \cdot \mathrm{m}^{-3}$ volume water content indicated by $<0.2$ WSI. These results support previous research that found 0.1 to $0.3 \mathrm{~m}^{3} \cdot \mathrm{m}^{-3}$ can be stressful soil moisture conditions for greenhouse-grown crops. Results also show that for substrates with similar substrates that irrigation set points can be reduced to $0.2 \mathrm{~m}^{3} \cdot \mathrm{m}^{-3}$ for improved irrigation efficiency.
\end{abstract}

Potted flowering plants are a resourceintensive crop because of the premium value for abundant, large, uniform blooms and defect-free foliage. Potted poinsettias [Euphorbia pulcherrima (Willd. ex Klotzsch) Graham] are one of the most valuable potted

\footnotetext{
Received for publication 18 Feb. 2020. Accepted for publication 24 May 2020.

Published online 8 July 2020.

We thank Galen Wolf, Jr., our lab assistant, who was essential in building the sensors; Meggie Lai and Casey O'Neil for assisting with data collection; and Melissa Scherr, Brent Warneke, Rebecca Sheridan, and the two anonymous reviewers for helpful contributions to the quality of the manuscript.

L.L.N. is the corresponding author. E-mail: Lloyd. Nackley@oregonstate.edu.

This is an open access article distributed under the CC BY-NC-ND license (https://creativecommons. org/licenses/by-nc-nd/4.0/).
}

flowering plants produced in the United States with an annual production value of $\approx \$ 149$ million, second only to orchids as the most valuable potted flowering plant (U.S. Department of Agriculture, 2019). Unlike many specialty crops where production is concentrated in a few regions, poinsettias are an important crop across the United States. Large production greenhouses in the South (Florida, North Carolina, South Carolina, and Texas), Northeast (New York, New Jersey, Maryland, and Pennsylvania), West (California), and Midwest (Ohio, Michigan, and Illinois) account for close to $85 \%$ of the U.S. poinsettia production (U.S. Department of Agriculture, 2019). The seasonality of poinsettia sales forces growers to ensure that the aesthetically pleasing subtropical plants are available to meet a limited winter-market window. Resources that promote plant growth rates, for example, water, fertilizer, pesticides, synthetic hormones, and supple- mental light and heat, are expensive (Ingram et al., 2016) and have unintended negative impacts when used in excess (White, 2013). It has been demonstrated that the intense growing period for potted poinsettia production has fostered management practices that favored excessive rates of fertilizer (Schuch et al., 1996).

Excessive irrigation creates pollution, is expensive, and promotes disease. Nutrientladen runoff from nurseries and greenhouses can be a significant environmental concern for both ground and surface water pollution (Majsztrik and Lea-Cox, 2013). Although runoff can create problems, in production systems where plants are grown in containers, some leaching of the soilless media is necessary to reduce the accumulation of soluble fertilizers in the root zone (Warren and Bilderback, 2005). Nursery irrigation best management practices recommend minimizing the leaching fraction, which is defined as the water leached divided by water applied (Pershey et al., 2015; Warren and Bilderback, 2005; Yeager et al., 2010), because excessive leaching will flush nutrients past the root zone, out of the container, and into groundwater and surface water. Flushing nutrients also represents significant economic losses in terms of wasted fertilizer and water. Fertilizers are one of the more expensive materials used in container plant production (Ingram et al., 2016). Although water is inexpensive in many production regions, it can represent a large cost for nursery and greenhouse plant production in arid regions, such as California and the southwestern United States (Pitton et al., 2018). Nonoptimized production practices, and overwatering in particular, are wasteful and deleterious in terms of increased poinsettia postproduction disease pressure (Guo et al., 2018) and decreased plant quality (Morvant et al., 1998). Excessive irrigation is known to promote the spread of waterborne plant pathogens (Redekar et al., 2019; Weiland et al., 2018) that cause millions of dollars in horticultural crop losses every year.

Improving agricultural water-use efficiency is important because of increasing competition for freshwater resources, occurrences of extreme weather, environmental pollution, energy use, and operating costs (Flörke et al., 2018; Hoekstra et al., 2012; Hoekstra and Chapagain, 2008). At the farm level, optimizing irrigation maximizes profits, and in a broader context, irrigation efficiency also maximizes social benefits (Letey, 2007). Research suggests that over the next 30 years there will be conflicts over water demand between the urban and agricultural sectors (Flörke et al., 2018; Hoekstra and Chapagain, 2008). Optimized irrigation strategies can have important on-farm and social benefits because improvements in agricultural water-use efficiency could free up enough water for urban uses for the majority of high water conflict regions (Flörke et al., 2018). One of the major causes of inefficient irrigation of specialty crops is a lack of basic information about the specific water required 
for optimal growth and yields (de Lima et al., 2015; Marin et al., 2016; Nemali and van Iersel, 2008). Optimized irrigation management requires properly quantifying the water volume to maximize plant growth without wasting this critical resource.

Sensor-based control systems can optimize irrigation schedules by triggering irrigation systems to replace the water transpired and evaporated from the storage zone (Lichtenberg et al., 2014; Majsztrik et al., 2013) while minimizing excessive leaching (Warner et al., 2018), improving flower yield and quality (Oki et al., 2001). By pairing sensors that monitor the environment with sensors that continuously monitor plant transpiration, we can determine how the volume of water required for plant growth fluctuates with environmental and physiological demand (Wheeler et al., 2019). For example, small young plants growing in cooler weather do not require as much water as large plants growing in warmer weather. Plants experience abiotic stress when photosynthesis is constrained by excessive or deficient temperature, light, nutrients, or water. Therefore, to optimize irrigation scheduling, it is essential to study plant yield and physiological responses to substrate moisture deficit. For herbaceous crops, leaf transpiration has been used as a nondestructive sensor-based assessment of plant water use (Guo et al., 2018; Kim et al., 2013; Nackley et al., 2014; Nambuthiri et al., 2017). Sap-flow sensors measure xylem flux, which is affected by the physiological interactions between the available water in the soil and the atmospheric demand and provide another nondestructive measurement of plant water use.

The application of sap-flow methods as a metric for woody plant physiology was pioneered by Huber and colleagues in the 1930s (Marshall, 1958). Unlike leaf transpiration measurements that are typically collected in discrete intervals with expensive sensors, sap-flow sensors are inexpensive to fabricate, can be automated for continuous xylem transpiration measurement, and are installed without disrupting the microclimate around the plant (Clearwater et al., 2009). Sap-flow sensors have not been used on many small stemmed and herbaceous crops because historically most sap-flow techniques involved the insertion of metal probes into the sapwood, which would damage or destroy delicate stems. However, research has shown that an external sap-flow technique (Clearwater et al., 2009) can be modified to be used in nursery systems (Nackley, 2019) to measure sap-flow on small-diameter stemmed plants like poinsettias. We hypothesized that correlating sap-flow sensors with substrate-moisture sensors and micrometeorology sensors would provide the necessary continuous data to optimize poinsettia irrigation. To improve irrigation efficiency and achieve water conservation benefits without sacrificing plant quality, growers need to know how their crops will respond to water deficits (Costa et al., 2007). For decades, crop water stress indices (CWSI or WSI) have been important tools for managing irrigation of agronomic and horticultural crops (Idso et al., 1981; Shackel et al., 1997; Testi et al., 2008). A WSI allows scientists to transform knowledge of how plants respond to water deficits into recommendations for irrigation management. Heretofore, for poinsettia the "ideal" setpoint for irrigation scheduling based on the needs of the plant is unknown. Therefore, the objective of this research was to use sap-flow measurements correlated with environmental data to develop a WSI for poinsettias.

\section{Materials and Methods}

Plant materials and growing conditions. Rooted cuttings of poinsettia (Euphorbia pulcherrima cv. Prestige Red) were individually potted into twelve 11-L black plastic nursery pots (C1200, Nursery Supplies Inc., Salem, OR). The potting medium consisted of a 1:1:1 blend of peat, sand, and redwood compost by volume with $2.68 \mathrm{~kg} \cdot \mathrm{m}^{-3}$ dolomite lime. This soilless medium had a bulk density of $0.49 \mathrm{~g} \cdot \mathrm{cm}^{-3}, 73 \%$ total porosity, and a $57 \%$ volumetric water content (VWC) at container capacity. Container substrate moisture was measured continuously VWC sensors (EC-5 sensor; Meter Group, Inc., Pullman, WA). The VWC sensors were calibrated in our laboratory by correlating the electrical signal generated by the sensor with gravimetric water content measurements collected sampling and drying the substrate mix at different water contents. After calibration, a VWC sensor was buried $\approx 10 \mathrm{~cm}$ from the bottom in each of the 12 pots. Potted plants were placed on a table in a naturally illuminated temperature-controlled glasshouse (Davis, CA, GPS 38.536479, $-121.7470306)$. The air temperature was measured with radiation-shielded thermocouples. Solar radiation at the canopy level was measured with a photosynthetically active radiation sensor ( $\mu \mathrm{mol}$ of photons $/ \mathrm{m}^{2} / \mathrm{s}$; LI-190, LI-COR Biosciences, Lincoln, NE) and a pyranometer sensor $\left(\mathrm{W} \cdot \mathrm{m}^{-2}\right.$; LI-200, LI-COR Biosciences). Pots were irrigated by an automatic system with two $8 \mathrm{~L} \cdot \mathrm{h}^{-1}$ drip emitters per pot. A soluble $20 \mathrm{~N}-3.9 \mathrm{P}-16.6 \mathrm{~K}$ fertilizer was injected into the irrigation water at a rate of $200 \mathrm{ppm} \mathrm{N}$. All of the potted plants were watered twice each week for 6 weeks.

After 6 weeks of growth, the 12 plants were randomly assigned one of three watering treatments: weekly, biweekly, and triweekly irrigation. The "weekly" plants were watered $1 \mathrm{~d}$ each week, "biweekly" plants were watered $1 \mathrm{~d}$ every 2 weeks, and "triweekly" plants were watered $1 \mathrm{~d}$ every 3 weeks. To refill the pot to container capacity on the scheduled watering date, water was applied for $7 \mathrm{~min}$ four times within a day with $1 \mathrm{~h}$ between irrigation events (i.e., 0600, 0700, 0800, $0900 \mathrm{HR}$ ). This type of pulseirrigation is considered a best management practice to allow for rewetting of the media to refill it to container capacity (Warren and Bilderback, 2005). All plants were grown for
$84 \mathrm{~d}$ under the irrigation treatments from 24 Aug. 2016 to 16 Nov. 2016.

Custom-made external sap-flow sensors were attached to the main stem of each plant at the start of the deficit irrigation treatments. Our external sap-flow sensors were inspired by Clearwater et al. (2009). Like most sapflow devices, ours consisted of a heating resistor and two thermocouples. The upstream thermocouple was located slightly closer $(1 \mathrm{~mm})$ to the heating resistor than the downstream (3-mm) thermocouple. The main difference between our device and the device described by Clearwater et al. (2009) is that we substituted the cork insulation with a half inch of foam insulation. We used a heat pulse velocity technique with our sap-flow sensors to measure a heat pulse released from the resistor and calculates velocity as a function of distance/time. The sap-flow sensors, the VWC sensors, the thermocouples, and the solar radiation sensors were connected to a data logger (CR1000; Campbell Scientific Inc., Logan, UT) and continuously monitored throughout the experiment. At the end of the experiment, plants were destructively harvested. We used a ruler to measure stem diameter at the location of the sap-flow sensor, plant height $(\mathrm{H})$ from the soil surface, and the width of the canopy in two directions. The first width $\left(\mathrm{W}_{1}\right)$ was measured at the widest point on the plant, and the second width $\left(\mathrm{W}_{2}\right)$ was measured perpendicular to $\mathrm{W}_{1}$. The three canopy dimension measurements were used to calculate a plant growth index $\left\{\mathrm{PGI}=\left[\left(\mathrm{W}_{1}+\mathrm{W}_{2}\right) / 2+\mathrm{H}\right] / 2\right\}$. Leaf area above the sensor and for the entire plant was measured by scanning the leaf images and calculating area with an image processing program (Image $\mathrm{J} v 1.5$; National Institute of Mental Health, Bethesda, MD). At the end of the experiment, all parts of the plants were dried in a forced-air oven for $48 \mathrm{~h}$ at $80{ }^{\circ} \mathrm{C}$, and the plant biomass was measured using a digital balance.

Sap-flow measurements. The temperature variation $\left(\Delta \mathrm{T}_{\mathrm{h}}\right)$ values were determined by temperature measurements at 10,90, 100, and $180 \mathrm{~s}$ after the start of the heat pulse and was calculated by:

$$
\Delta \mathrm{T}_{\mathrm{h}}=\frac{\left(\mathrm{T}_{90}-\mathrm{T}_{10}\right)+\left(\mathrm{T}_{180}-\mathrm{T}_{100}\right)}{2},
$$

where $\Delta \mathrm{T}_{\mathrm{h}}=$ temperature changes in the plant during the pulse; $\mathrm{T}_{10}=$ temperature measured by the sensor at $10 \mathrm{~s}$ after the start of the pulse; $\mathrm{T}_{90}=$ temperature measured by the sensor at $90 \mathrm{~s}$ after the start of the pulse; $\mathrm{T}_{100}=$ temperature measured by the sensor at $100 \mathrm{~s}$ after the end of the pulse; and $\mathrm{T}_{180}=$ temperature measured by the sensor at $180 \mathrm{~s}$ after the end of the pulse.

The actual output of the sensor was defined as $(\Lambda)$ :

$$
\Lambda=1-\frac{\Delta \mathrm{T}_{\mathrm{h}}}{\Delta \mathrm{T}_{\mathrm{h}}^{0}},
$$

where $\Lambda=$ sensor signal; $\Delta \mathrm{T}_{\mathrm{h}}^{0}=$ temperature range measured by the sensor installed in the plant at zero flow condition; and $\Delta \mathrm{T}_{\mathrm{h}}=$ 
temperature range measured by the sensor installed in the plant at one point in time during the day.

Assuming a linear relationship between the signal measured by the sensor and sapflow, the amount of sap-flow can be estimated as follows:

$$
\mathrm{J}=\mathrm{k} \cdot \Lambda,
$$

where $\mathrm{J}=$ sap-flow density, that is, the flow divided by the area of conducting tissue $\left(\mathrm{m}^{3} \cdot \mathrm{s}^{-1} \cdot \mathrm{m}^{-2}\right)$; and $\mathrm{k}=$ coefficient based on the diffusivity and thermal capacity of the stem and the sap, and the sensor geometry $\left(\mathrm{m}^{3} \cdot \mathrm{s}^{-1} \cdot \mathrm{m}^{-2}\right)$ similar to Grainier thermal dissipation coefficient (Granier).

Developing water stress index. The soil plant atmosphere continuum (SPAC) assumes that the volume of water that moves from the soil, passing through the plant, and reaches the atmosphere is the same $\left(\mathrm{V}_{\text {soil }}=\right.$ $\mathrm{V}_{\text {plant }}=\mathrm{V}_{\text {atm }}$ ).

Therefore, the volume of water extracted from the soil each day $\left(\mathrm{V}_{\text {soil }}\right)$ can be estimated by:

$$
V_{\text {soil }}=V_{p s} \Delta \theta_{s},
$$

where $V_{p s}=$ the soil volume explored by plant root $\left(\mathrm{m}^{3}\right)$; and $\Delta \theta_{s}=$ daily variation of the water content in the soil $\left(\mathrm{m}^{3} \cdot \mathrm{m}^{-3} \cdot \mathrm{d}^{-1}\right)$.

The water volume that passes through the plant $\left(\mathrm{V}_{\text {plant }}\right)$ can be estimated by:

$$
V_{\text {plant }}=\bar{J} S_{s} \frac{L_{p}}{L_{s}}
$$

where $\bar{J}=$ sap-flow density $\left(\mathrm{m}^{3} \cdot \mathrm{m}^{-2} \cdot \mathrm{d}^{-1}\right) ; S_{s}=$ transversal area of the stem at the position of the sensor $\left(\mathrm{m}^{2}\right) ; L_{s}=$ leaf area for the plant above where the sensor is positioned $\left(\mathrm{m}^{2}\right)$; and $L_{p}=$ total leaf area of the plant $\left(\mathrm{m}^{2}\right)$.

The water volume that reaches the atmosphere $\left(V_{\text {atm }}\right)$ is estimated by:

$$
V_{\text {atm }}=h E T_{H S},
$$

where $V_{\text {atm }}=$ water volume that is lost to the atmosphere $\left(\mathrm{m}^{3} \cdot \mathrm{d}^{-1}\right) ; E T_{H S}=$ air demand based on the Hargreaves-Samani (HS) equation $\left(\mathrm{mm} \cdot \mathrm{d}^{-1}\right)$; and $h=$ adjusted coefficient $\left(\mathrm{m}^{3} \cdot \mathrm{mm}^{-1}\right)$

$$
\begin{aligned}
\text { Because } \mathrm{V}_{\text {soil }} & =\mathrm{V}_{\text {plant }}=\mathrm{V}_{\mathrm{atm}}, \\
V_{p s} \Delta \theta_{s} & =\bar{J} S_{s} \frac{L_{p}}{L_{s}}=h E T_{H S} .
\end{aligned}
$$

Therefore, at the end of the experiment, it was possible to estimate the daily variation of the water content in the soil, $\mathrm{m}^{3} \cdot \mathrm{m}^{-3} \cdot \mathrm{d}^{-1}\left(\Delta \theta_{s}\right)$ from the transversal area of the stem at the position of the sensor $\left(S_{s}\right)$, the soil volume explored by plant root $\left(V_{p s}\right)$, the leaf area of the stem where the sensor is positioned $\left(L_{s}\right)$, and the leaf area of the plant $\left(L_{p}\right)$.

$$
\begin{aligned}
\Delta \theta_{s} & =\bar{J} \frac{S_{s}}{V_{p s}} \frac{L_{p}}{L_{s}} \\
& =\overline{\mathrm{k} \cdot \Lambda} \frac{S_{s}}{V_{p s}} \frac{L_{p}}{L_{s}}=\alpha \bar{\Lambda}
\end{aligned}
$$

Alpha is used to integrate the units because the soil moisture sensors record as $\mathrm{m}^{3} \cdot \mathrm{m}^{-3}$ and the sap flow sensors record as $\mathrm{m}^{3} \cdot \mathrm{m}^{-2} \cdot \mathrm{s}^{-1} ; \alpha$ reflects the leaf architecture of each plant measured, which is expressed by the relation $\frac{S_{s}}{V} \frac{L_{p}}{L}$ and the thermal properties and geometry of the sensor (k). "What-IfAnalysis" (Solver function, Microsoft Excel 2015; Microsoft Inc., Redmond, WA) was used to interactively change the values of $\alpha$ to minimize the difference between two terms of Eq. [9].

Seven dates were chosen between the start of the experiment, 24 Aug. 2016, through 16 Nov. 2016, at 14-day intervals. In days between the 14-day intervals, the value of $\alpha$ was calculated by

$$
\alpha_{i}=\alpha_{b}+\frac{\left(\alpha_{e}-\alpha_{b}\right)}{\left(d_{e}-d_{b}\right)}\left(d_{i}-d_{b}\right),
$$

where $\alpha_{i}=$ value $\alpha$ for date $i ; \alpha_{b}, \alpha_{e}=$ value $\alpha$ for the date in the beginning and the end of the interval; $d_{b}, d_{e}=$ date of the beginning and the end of the interval; and $d_{i}=$ date $i$.

SPAC assumes that when a plant was not water stressed, it was possible to relate the plant's water consumption (WC) with the atmospheric demand.

The air demand was estimated from the HS equation:

$E T_{H S}=0.0023 R a \sqrt{T_{m x}-T_{m n}}\left(17.8+T_{a v}\right)$,

where $E T_{H S}=$ reference evapotranspiration HS equation $\left(\mathrm{mm} \cdot \mathrm{d}^{-1}\right) ; \mathrm{Ra}=$ extraterrestrial radiation (evaporation equivalent) $\left(\mathrm{mm} \cdot \mathrm{d}^{-1}\right)$; $T_{m x}=$ daily maximum temperature $\left({ }^{\circ} \mathrm{C}\right)$; $T_{m n}=$ daily minimum temperature $\left({ }^{\circ} \mathrm{C}\right)$; and $T_{a v}=$ daily average temperature $\left({ }^{\circ} \mathrm{C}\right)$.

When a plant was not water stressed, it was possible to express the plant $\mathrm{WC}\left(W C_{n s}\right)$ as:

$$
W C_{n s}=\bar{J} S_{s} \frac{L_{p}}{L_{s}}=h E T_{H S}
$$

from Eq. [8]:

$$
W C_{n s}=V_{p s} \alpha_{n s} \bar{\Lambda}=h E T_{H S}
$$

or:

$$
\frac{W C_{n s}}{V_{p s}}=\alpha_{n s} \bar{\Lambda}=\frac{h}{V_{p s}} E T_{H S}=h^{\prime} E T_{H S}
$$

in analog form, when the plants were stressed:

$$
\frac{W C_{a}}{V_{p s}}=\alpha \bar{\Lambda}
$$

The $h^{\prime}$ value is used to relate $E T_{H S}$ with WC (Eq. [15]). $h^{\prime}$ was calculated when the plant(s) were not water stressed. We assumed plants were not water stressed 2 to $3 \mathrm{~d}$ after an irrigation event if substrate moisture levels, when measured by the soil moisture sensors, were $>0.3 \mathrm{~m}^{3} \cdot \mathrm{m}^{-3}$. What-If-Analysis (Solver function, Microsoft Excel 2015; Microsoft Inc.) was used again to interactively minimize the difference between the two terms in the equation: WC based on sap flow measurement (WC) and the WC based on environmental demand (ET). We estimated the $h$ value during the interval while soil moisture was $>0.3 \mathrm{~m}^{3} \cdot \mathrm{m}^{-3}$ by using an equation similar to Eq. [9]. After the $h^{\prime}$ values were deter- mined it was possible to calculate a water stress index as:

$$
W S I=1-\frac{W C_{a}}{W C_{n s}}=1-\frac{\alpha \bar{\Lambda}}{h^{\prime} E T_{H S}},
$$

where $W S I=$ water stress index (dimensionless); $W C_{a}=$ the $\mathrm{WC}$ of the plant $\left(\mathrm{m}^{3} /\right.$ plant based on $\bar{J} S_{s} \frac{L_{p}}{L_{s}}$ ); and $h^{\prime} E T_{H S}=$ potential WC of the plant under ideal conditions ( $\mathrm{m}^{3} /$ plant).

Statistical analysis. The experiment was a replicated completely randomized design. The three irrigation treatments were considered as categorical variables. One-way analyses of variance were used to compare the amount of variance that was contributed by the different watering treatments to the growth response variables including leaf area, biomass, and PGI. Plant WC and water stress responses were affected by the irrigation treatment and the environment. We used analysis of covariance (ANCOVA) models with type III sums of squares to investigate the influence of treatment and substrate moisture content. For these models, irrigation was treated as a grouping variable and substrate moisture content was treated as a continuous covariate. We specified orthogonal contrasts so that the sums of squares for the irrigation treatment groups were completely partitioned and nonoverlapping. When treatments were found to be significantly different $(P<$ 0.05 ) we used Holm-Sidak pairwise comparisons. Holm-Sidak pairwise comparisons are considered more powerful than Tukey and Bonferroni tests and are recommended as a first-line procedure for most multiple comparison testing (Systat Software, San Jose, $\mathrm{CA})$. Linear regression $(\mathrm{y}=\mathrm{mx}+\mathrm{b})$ was used to describe the relationship between estimated daily water consumption and daily water depletion measured by the soil moisture sensors. An exponential decay model $[y=a * \exp (-b * x)]$ was used to predict the relationship between WSI and volumetric water content. Statistical analyses were completed using the $\mathrm{R}$ software program (R Core Team, 2013, Vienna, Austria). Figures were plotted with SigmaPlot software (Systat Software).

\section{Results}

The greenhouse provided consistent daily mean and minimum growing temperatures throughout the experiment $($ mean $=21.5 \pm$ $0.9^{\circ} \mathrm{C}$ and minimum $=16.7 \pm 0.4{ }^{\circ} \mathrm{C}, \mathrm{n}=84$ ). The maximum temperature was more affected by the seasonality. The mean maximum (max.) temperature was $30 \pm 2.9{ }^{\circ} \mathrm{C}$. Maximum temperatures during the first 2 months (August-October) were consistently $>30{ }^{\circ} \mathrm{C}$ and consistently $<30{ }^{\circ} \mathrm{C}$ during the final 2 months (October-December). The light environment in the natural light greenhouse also decreased from August to December. The mean monthly daily light integrals from August through December were 24.4, 21.1, 16.7, 11.1, and 9.1. The temperature data were used in the HS equation to model environmental demand. The $\mathrm{ET}_{\mathrm{HS}}$ model 


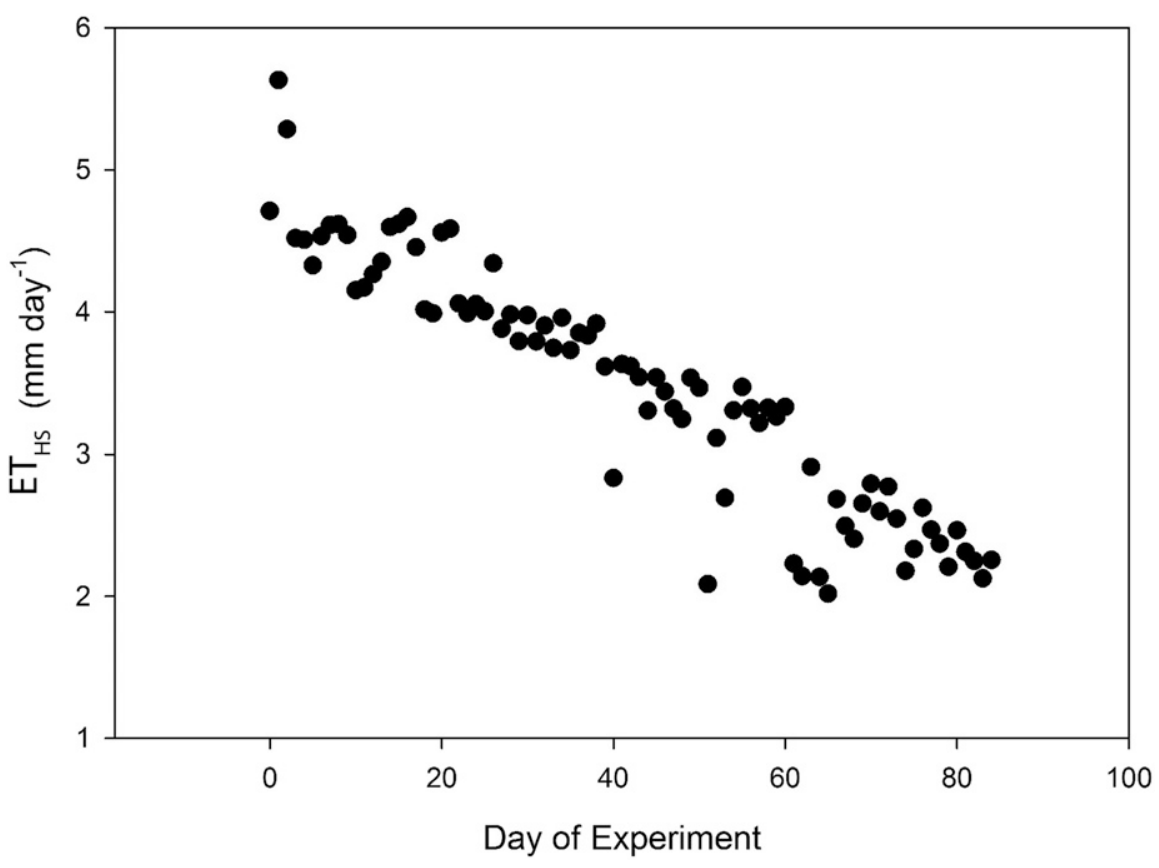

Fig. 1. The Hargreaves-Samani ( $\left.\mathrm{ET}_{\mathrm{HS}}\right)$ model was used as an environmental demand index. All plants were grown for $84 \mathrm{~d}$ under the irrigation treatments from 24 Aug. 2016 to 16 Nov. 2016. The model predicts decreasing environmental demand toward the winter months illustrated in the figure above by the decreasing $\mathrm{ET}_{\mathrm{HS}}$ values over time.

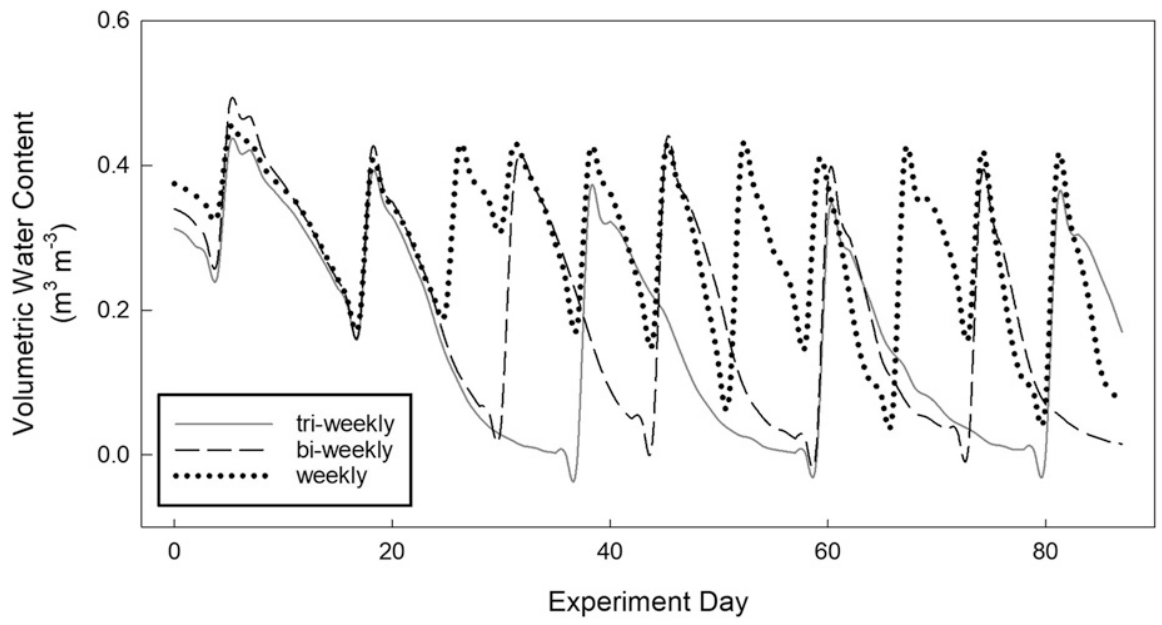

Fig. 2. The variable irrigation scheduling was used to generate different levels of plant stress. The data were collected with volumetric soil moisture sensors (EC-5, Meter Group) and demonstrate the clear differences in the duration of moisture conditions reported to be limiting for greenhouse-grown plants $\left(<0.3 \mathrm{~m}^{3} \cdot \mathrm{m}^{-3}\right)$

calculated a decreasing environmental demand toward the winter months (Fig. 1). The irrigation treatments effectively created the variable periods of moisture deficit, with the triweekly watering schedule having the most prolonged deficit (Fig. 2).

Plant growth is the integrated expression of experimental conditions. Plant growth was correlated with the watering treatments with more frequent irrigation producing larger plants. (Table 1). The average weekly watered plants were taller, had a greater canopy volume (PGI), and had greater total leaf area than biweekly plants watered and sured by the VWC sensors $\left(\Delta \theta_{\mathrm{s}}\right)$ with the estimated daily consumption measured by the sap-flow sensors (Eq. [3]) with the $\alpha$ value correction (Eq. [9]). The data suggested a high correlation between our plantbased, sap-flow measurements, and actual substrate moisture measurements (Fig. 3). The correlation coefficient of our estimates was greater for drought treatment groups (triweekly: $R^{2}=0.84$, biweekly: $R^{2}=0.83$ ) than the weekly watered group (w: $R^{2}=$ 0.70 ).

The WSI (Eq. [12]) was generated by subtracting the ratio of sap-flow measured water consumption $\left(\mathrm{m}^{3} /\right.$ plant $)$ to ET estimated potential water consumption $\left(\mathrm{m}^{3} /\right.$ plant) from 1 to create an index ranging from 0 to 1 . A WSI of 0 indicated a plant with no water stress. A WSI $>0$ indicated that the plant was transpiring less than would be estimated by environmental conditions and therefore was expressing plant stress. A WSI of 1 indicated extreme stress that the plant is not transpiring regardless of environmental demand. The majority $(>50 \%)$ of the weekly treatment plants begin expressing water stress $<0.33 \mathrm{~m}^{3} \cdot \mathrm{m}^{-3}$. The majority of the biweekly treatment plants begin expressing water stress $<0.27 \mathrm{~m}^{3} \cdot \mathrm{m}^{-3}$, whereas the majority of triweekly treatment plants began expressing water stress $<0.18 \mathrm{~m}^{3} \cdot \mathrm{m}^{-3}$. For all plants, we plotted the WSI against measured VWC $\left(\mathrm{m}^{3} \cdot \mathrm{m}^{-3}\right)$ and used an exponential decay function to best describe the relationship between available soil moisture and water stress. The regression curve was more closely related to the triweekly group $\left(R^{2}=\right.$ 0.89 ), and described the majority of the variability in the biweekly $\left(R^{2}=0.80\right)$ and weekly $\left(R^{2}=0.72\right)$ treatment groups (Fig. 4). ANCOVA suggested that there were significant differences between the watering treatments (WSI $\sim$ group + SMS). This significant difference is visualized in the plots by the shift in WSI along the $\mathrm{x}$-axis (Fig. 4).

\section{Discussion}

We were able to continuously measure plant transpiration by quantifying from the ratio of the temperature differences between the two probes, which was inherently affected by the flow of root absorbed water that was transported upward (acropetally). This method has previously been validated for plant transpiration measurements (de Oliveira Reis et al., 2006; Granier, 1987). We were able to correlate transpiration with soil moisture to develop a WSI for potted poinsettias. Our results suggest that the plants in the weekly treatment group did not experience water stress until $0.32 \mathrm{~m}^{3} \cdot \mathrm{m}^{-3}$. Previous research of other greenhouse-produced floriculture crops grown in soilless media reported that "low" soil moisture levels $\left(0.15\right.$ to $\left.0.22 \mathrm{~m}^{3} \cdot \mathrm{m}^{-3}\right)$ were an optimal range because leaf $\mathrm{CO}_{2}$ assimilation was unaffected even when leaf transpiration was significantly decreased (Nemali and van Iersel, 2008). Conversely, other research of 
Table 1. Average (mean) poinsettia growth results $( \pm \mathrm{SD})$ for the three irrigation frequencies. Results $(P$ values) from the one-way analysis of variance and Holm-Sidak pairwise comparisons are listed in the lower half of each growth category (e.g., height). Treatments were considered statistically different if $P<0.05$.

\begin{tabular}{lccc}
\hline Treatment & Ht $(\mathrm{cm})$ & Plant growth index & Leaf area $\left(\mathrm{m}^{2}\right)$ \\
\hline Weekly & $67.4 \pm 2.7 \mathrm{a}^{\mathrm{z}}$ & $83.4 \pm 1.9 \mathrm{a}$ & $2.91 \pm 0.17 \mathrm{a}$ \\
Biweekly & $57.0 \pm 6.3 \mathrm{~b}$ & $61.3 \pm 3.6 \mathrm{~b}$ & $1.22 \pm 0.13 \mathrm{~b}$ \\
Tri-weekly & $49.0 \pm 3.1 \mathrm{c}$ & $57.1 \pm 4.1 \mathrm{~b}$ & $0.93 \pm 0.08 \mathrm{c}$ \\
$P$ value & $<0.001$ & $<0.001$ & $<0.001$ \\
\hline
\end{tabular}

${ }^{\mathrm{z}}$ Significant differences between treatments are indicated by different lowercase letters to the right of each set of descriptive statistics (average \pm SD).
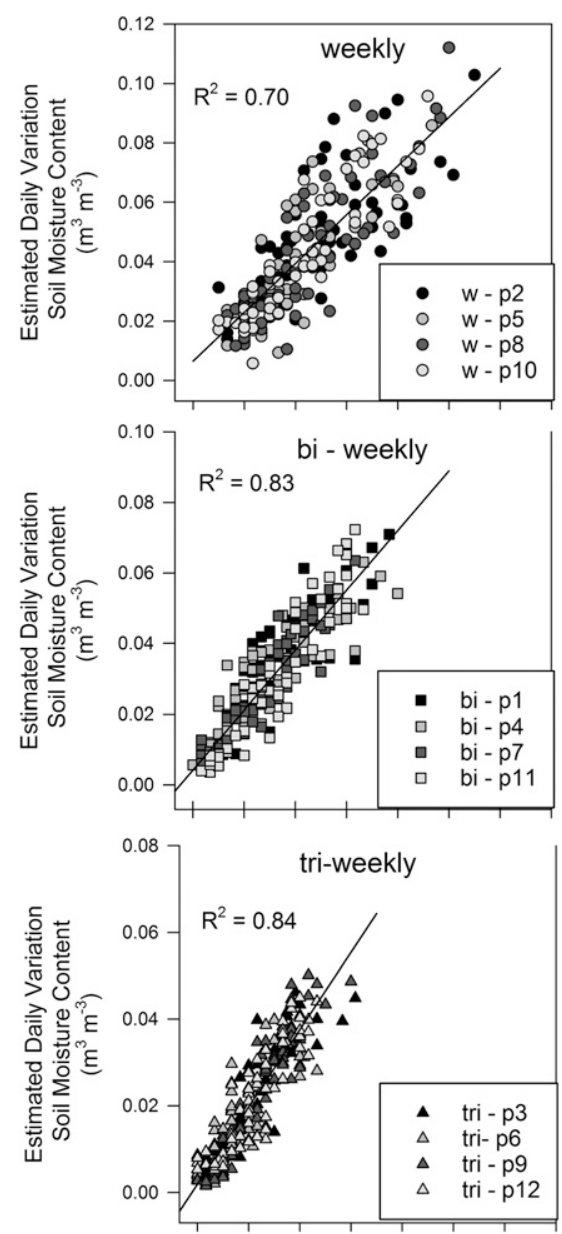

$\begin{array}{llllllll}0.00 & 0.02 & 0.04 & 0.06 & 0.08 & 0.10 & 0.12 & 0.14\end{array}$

\section{Measured Daily Variation} $\left(\mathrm{m}^{3} \mathrm{~m}^{-3}\right)$

Fig. 3. For sap-flow measurements to be comparable to substrate moisture measurements, the $\alpha$ value correction (Eq. [9]) was required to create equivalent measurement units. To assess the performance of the $\alpha$ adjustment, these graphs are used to correlate the daily variation of the water measured by soil moisture sensors and the daily variation of the water estimated by sap-flow sensors. The correlations are used to test part of the soil plant atmosphere continuum (SPAC), which assumes that the volume of water that moves from the soil, passing through the plant, and reach the atmosphere is the same, $\mathrm{V}_{\text {soil }}=\mathrm{V}_{\text {plant }}=\mathrm{V}_{\mathrm{atm}}$.

greenhouse-produced floriculture crops grown in soilless media measured significant decreases in both leaf $\mathrm{CO}_{2}$ assimilation and transpiration at a similar soil moisture range $\left(0.1\right.$ to $\left.0.3 \mathrm{~m}^{3} \cdot \mathrm{m}^{-3}\right)$ (Niu et al., 2006). These contrasting examples illustrate the difficulty of developing broader inferences because there are few references of physiological responses of greenhouse-grown floriculture varieties. Moreover, plant physiological responses to moisture deficit are also complex and often nonlinear, even for commonly reported transpiration metrics such as leaf transpiration and xylem sap flow (de Oliveira Reis et al., 2006). However, some generalities can be used to inform irrigation management. For example, plant responses to decreasing soil moisture have been described in a hydraulic framework of physiological regulation strategies that balance $\mathrm{CO}_{2}$ uptake and water loss to prevent carbon starvation and hydraulic failure, which are the two major mechanisms of droughtinduced mortality (McDowell et al., 2008; Skelton et al., 2015).

Plant hydraulics physiology, the study of water movement from roots to leaves, is applicable for understanding the response of horticultural plants to changes in irrigation management. Plant hydraulic stress can be quantified as decreases in physiological processes that promote growth and are related to the movement of water. The timing, intensity, and duration of hydraulic stress (aka drought stress) are pivotal to determine the effects produced by water deficits (Chaves and Oliveira, 2004). Irrigated crops can express periodic stress when daily evaporative demand exceeds available soil moisture (Bryla et al., 2011; Miralles-Crespo and van Iersel, 2011). Managing production practices to prevent drought stress can be difficult in nursery and floriculture systems where different crops often share overhead sprinklers because plants respond differently to soil moisture. Plants vary considerably with respect to stomatal closure as a protective mechanism against water shortage, which is why continual monitoring of transpiration may be better for understanding drought response and irrigation scheduling than instantaneous leaf gas exchange measurements. Continuous plant physiological responses to environmental gradients can then be modeled to determine thresholds when a specific plant function decreases.

An optimized irrigation schedule for potted poinsettias should be designed to replace substrate moisture before the plants begin exhibiting symptoms of stress. Traditional irrigation management strategies attempt to maintain substrate water content at close to container capacity to achieve optimal water availability (Jones, 2004). For many potting substrates, container capacity is 0.6 to 0.4 $\mathrm{m}^{3} \cdot \mathrm{m}^{-3}$ VWC. Our results indicate that poinsettia irrigation schedules that attempt to maintain $0.4 \mathrm{~m}^{3} \cdot \mathrm{m}^{-3} \mathrm{VWC}$ are applying excessive volumes of water, resulting in wasted resources and potential sources of pollution. It has been suggested that a standard commercial production irrigation schedule allows the substrate to dry down to $0.4 \mathrm{~m}^{3} \cdot \mathrm{m}^{-3} \mathrm{VWC}$ before rewatering to container capacity (Guo et al., 2018). Our results suggest that it was not until $<0.2 \mathrm{~m}^{3} \cdot \mathrm{m}^{-3} \mathrm{VWC}$ that most of the weekly treatment plants began expressing water stress symptoms. A water-restricted grower using similar substrates could target these lower thresholds from 0.4 to 0.2 $\mathrm{m}^{3} \cdot \mathrm{m}^{-3}$ to achieve $50 \%$ savings of applied water. Although VWC is a common metric in research and commercial greenhouse operations, from a plant physiological perspective, tension-based measurements provide more biophysical information and are translatable across soils and soilless-media types.

The degree of water stress is closely related to the increasing tension required for the plant to overcome to extract water from the soilless media. A previously reported moisture release curve for the substrate medium used in our experiment indicated that during the decrease from 0.3 to $0.2 \mathrm{~m}^{3} \cdot \mathrm{m}^{-3}$ VWC, there was an exponential increase in tension from $-5 \mathrm{kPa}$ (suboptimal conditions) to $-20 \mathrm{kPa}$ (wilting conditions; Kiehl et al., 1992). A biophysical response by the poinsettia that reflected the exponential increase in soil-moisture tension was captured by our sap-flow sensors and illustrated by the rapid rise of the WSI (Fig. 4). In the 0.3 to 0.2 $\mathrm{m}^{3} \cdot \mathrm{m}^{-3}$ VWC range, the plants in our study experienced low to high water stress. From our findings, we can state that for this potting medium and other substrates with similar physical properties, soil moisture $>0.3$ $\mathrm{m}^{3} \cdot \mathrm{m}^{-3}$ VWC represents "easily available water," and the soil moisture in the 0.3 to $0.2 \mathrm{~m}^{3} \cdot \mathrm{m}^{-3}$ range represents more of the "water buffering capacity" for poinsettias. Easily available water is sometimes also called readily available water that is accessible at relatively low tensions and is the predominant $75 \%$ to $80 \%$ of the total amount of available water by plants (de Boodt and Verdonck, 1972). Water buffering capacity has been defined as the water available in the substrate needed when sudden heat waves occur, resulting in intense transpiration (de Boodt and Verdonck, 1972).

Greenhouses mitigate environmental extremes to facilitate plant growth, yet temperature and solar radiation within our natural-lit greenhouse was still driven by the dominant seasonality of our latitude $\left(38.536479^{\circ}\right.$ $\mathrm{N})$. The HS evapotranspiration (HS-ET) (Hargreaves and Allen, 2003; Samani, 2000) is a simplified equation that requires only temperature and latitude and is appropriate in situations like ours that have limited environmental sensors (Luo et al., 2014; 

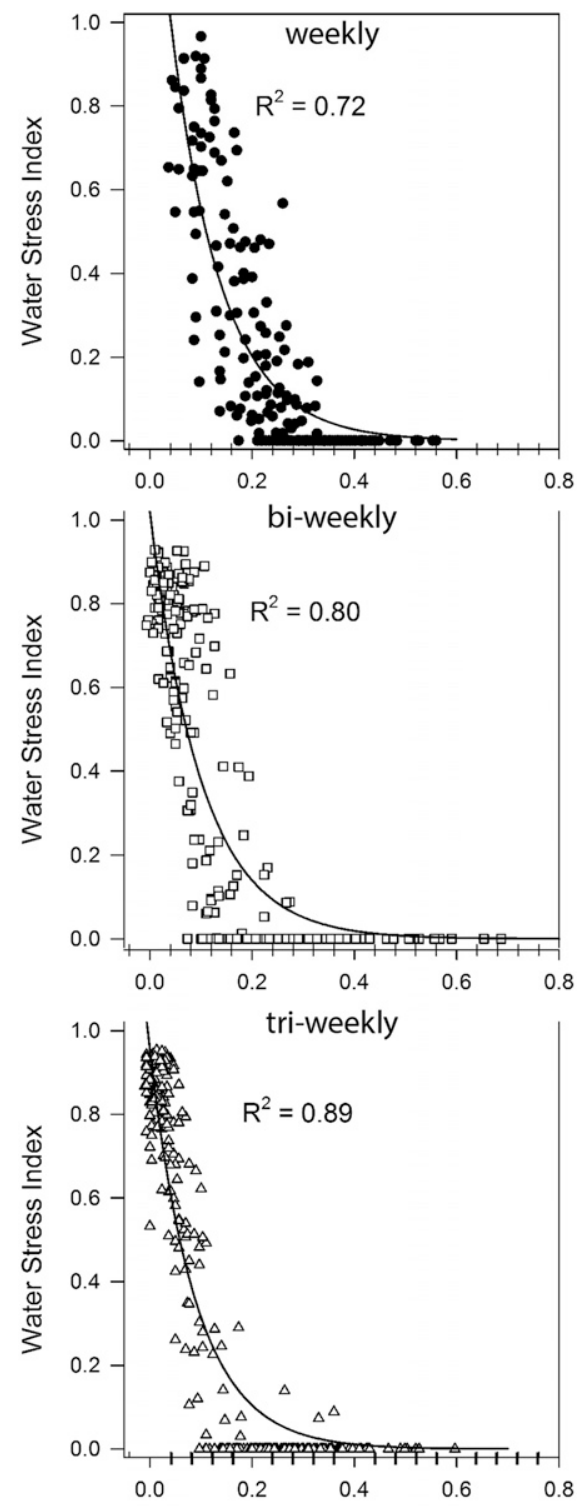

Vol. Moist. Cont. $\left(\mathrm{m}^{3} \mathrm{~m}^{-3}\right)$

Fig. 4. The water stress index (WSI) was generated by subtracting the ratio of sap-flow measured water consumption to evapotranspiration estimated potential water consumption from 1 . The majority of triweekly treatment plants began indicating water stress at $<0.2 \mathrm{~m}^{3} \cdot \mathrm{m}^{-3}$, compared with $<0.25 \mathrm{~m}^{3} \cdot \mathrm{m}^{-3}$ for biweekly treatment plants and $<0.3 \mathrm{~m}^{3} \cdot \mathrm{m}^{-3}$ for the weekly treatment plants. Our results suggest that the plants in the weekly treatment group did not experience water stress until $0.3 \mathrm{~m}^{3} \cdot \mathrm{m}^{-3}$, as indicated by a WSI $<0.2$.

Raziei and Pereira, 2013). Solar radiation expressed in $\mathrm{MJ} \cdot \mathrm{m}^{-2} \cdot \mathrm{d}^{-1}$ can be converted to equivalent evaporation in $\mathrm{mm} \cdot \mathrm{d}^{-1}$ by using a factor equal to the inverse of the latent heat of vaporization (Allen et al., 1998). However, we are not using HS-ET model to predict irrigation needs. Although ET is a common method for scheduling irrigation of field crops, because transpiration is influenced to a large degree by the plant stomata, ET is inaccurate for specialty horticultural crops due to the anisohydric responses to moisture deficits (Ferraz et al., 2015). ET is the sum of evaporation and transpiration; therefore, we use the HS-ET model as a proxy to estimate relative environmental demand paired with transpiration measurements from the sapflow sensors on the plant. This balance of demand vs. transpiration was incorporated into our WSI as a ratio.

Plants must obtain enough water to meet the evaporative demand for transpiration. When water supplies are insufficient, stomata close and leaf temperatures begin to rise. A widely used CWSI measures crop canopy temperature, ambient air temperature, and relative humidity to determine plant water status (Idso et al., 1981; Jackson et al., 1988; Testi et al., 2008). Our method is similar in that it measures the effects of stomatal closure. However, where the methods of Idso et al. (1981) have been criticized as less useful in more humid or cloudy climates (Jones, 2004), our method is robust in any climate. It has been reported that sap flow methods are more accurate than thermographic CWSI which have been found to underestimate crop water stress in deficit irrigated field crops (Han et al., 2018). The superiority of sap flow compared with thermography was also demonstrated in orchard crops, where sap flow was capable of following the diurnal dynamics of stress (Agam et al., 2013). Similarly, sap flow measurements have previously been correlated with leaf water potential measurements to describe daily drought stress curves for apple trees (Nadezhdina, 1999). Similar to our findings, stem-water potential is another SPAC based WSI that has been widely used in fruit trees and vineyards (Levin, 2019; Shackel et al., 1997). A benefit of sap-flow measurements, compared with pressure chamber measures, is that sap flow can be automatically collected over long periods and can be integrated with automated irrigation systems.

Deficit irrigation programs apply less water than volumes demanded by ET. Some studies have shown how deficit irrigation can be beneficial for ornamental crops. For a variety of container plants, mild deficit irrigation strategies have resulted in greater plant growth (Bergeron et al., 2004; Fulcher et al., 2012; Welsh and Zajicek, 1993). Rhododendron plants grown under deficit irrigation had increased flowering (Scagel et al., 2012). For poinsettias, deficit irrigation has been sought after as a replacement for plant growth regulators (PGR). For example, poinsettia height was effectively controlled by periodically allowing containers to dry down from 0.40 to $0.20 \mathrm{~m}^{3} \cdot \mathrm{m}^{-3}$ in $80: 20$ peat perlite potting mix (Alem et al., 2015). For ornamental plants such as poinsettias, it is essential to improve irrigation efficiency and achieve water conservation benefits without sacrificing plant quality. Guo et al. (2018) demonstrated how irrigation thresholds at $0.2 \mathrm{~m}^{3} \cdot \mathrm{m}^{-3}$ VWC for a peat-based substrate could create stunting without degrading aesthetics as a chemical-free alternative to ap- plications of PGR such as chlormequat and paclobutrazol. Their research also pointed to reduced disease pressure for plants watered with deficit irrigation schedules (Guo et al., 2018), which has also been found in other deficit irrigated nursery systems (Dumroese and James, 2005). Using deficit irrigation may not only be useful for conserving water but can also be a tool to attain other production standards. For example, there is evidence that excessive irrigation of poinsettia created lower quality, excessively lush, and weak growth (Morvant et al., 1998). The biweekly and triweekly watered plants in this study were significantly smaller than the weekly treatment group. The plants in our study were not assessed for marketability, primarily because we did not have lighting capability to induce and manage flowering. However, our results do suggest irrigation thresholds that may be refined through production deficit irrigation trials.

There are opportunities for additional research to evaluate whether the responses we discovered are consistent across other growing media and how PGR, which were not used in our trial but are commonly sprayed on poinsettias, affect transpiration. Although our study differs in many aspects (e.g., experimental design and physiological measures) from the Guo et al. (2018) research, our results provide complementary evidence supporting the idea of decreasing poinsettia irrigation scheduling by $50 \%$ from 0.4 to 0.2 $\mathrm{m}^{3} \cdot \mathrm{m}^{-3}$ VWC. This is not the first time research could influence radical changes to poinsettia production. The potential for $50 \%$ savings in water use echoes earlier research demonstrating the possibility of a $50 \%$ decrease in nitrogen fertilization while achieving aesthetically acceptable poinsettias (Schuch et al., 1996). Significant savings in water use may be especially prized in poinsettia production regions with water quality and quantity restrictions. For example, 7 million poinsettia plants-more than $20 \%$ of all U.S. production - are grown in California (U.S. Department of Agriculture, 2019). California is a state that is perennially afflicted by drought, resulting in competition for limited water resources and high prices for water (Pitton et al., 2018). In large production regions that are not water-limited, such as Florida and North Carolina, where combined production of more than 6 million poinsettia plants represents close to $18 \%$ of U.S. production (U.S. Department of Agriculture, 2019), there are regulations ensuring standards for agricultural water quality. $\mathrm{Nu}-$ trient and irrigation best management practices in these regions call for improving the efficiency of water and fertilizer use to maintain profitability while protecting the environment (Wilson et al., 2010; Yeager et al., 2010). There are legitimate questions about the validity of using plants as indicators for irrigation management, including several open issues, such as which plants to measure, how many replicates per area are needed, and what water stress limits are relevant to production methods (Lousada et al., 2015). We 
believe that by pairing sensors that monitor the environment with sensors that continuously monitor plant transpiration, our study provides an excellent first step toward answering some of these questions for one of the most important and widespread floriculture crops in the United States.

\section{Literature Cited}

Agam, N., Y. Cohen, J.A.J. Berni, V. Alchanatis, D. Kool, A. Dag, U. Yermiyahu, and A. BenGal. 2013. An insight to the performance of crop water stress index for olive trees. Agr. Water Mgt. 118:79-86.

Alem, P., P.A. Thomas, and M.W. van Iersel. 2015. Controlled water deficit as an alternative to plant growth retardants for regulation of poinsettia stem elongation. HortScience 50:565-569.

Allen, R.G., L.S. Pereira, D. Raes, and M. Smith. 1998. Crop evapotranspiration: Guidelines for computing crop water requirements. Food and Agriculture Organization Irrigation and Drainage Paper No. 56. Rome, Italy.

Bergeron, O., M.S. Lamhamedi, H.A. Margolis, P.Y. Bernier, and D.C. Stowe. 2004. Irrigation control and physiological responses of nurserygrown black spruce seedlings $(1+0)$ cultivated in air-slit containers. HortScience 39:599-605.

Bryla, D.R., J.L. Gartung, and B.C. Strik. 2011. Evaluation of irrigation methods for highbush blueberry: Growth and water requirements of young plants. HortScience 46:95-101.

Chaves, M.M. and M.M. Oliveira. 2004. Mechanisms underlying plant resilience to water deficits: Prospects for water-saving agriculture. J. Expt. Bot. 55:2365-2384.

Clearwater, M.J., Z. Luo, M. Mazzeo, and B. Dichio. 2009. An external heat pulse method for measurement of sap flow through fruit pedicels, leaf petioles and other small-diameter stems. Plant Cell Environ. 32:1652-1663.

Costa, J.M., M.F. Ortuño, and M.M. Chaves. 2007. Deficit irrigation as a strategy to save water: Physiology and potential application to horticulture. J. Integr. Plant Biol. 49:1421-1434.

de Boodt, M. and O. Verdonck. 1972. The physical properties of the substrates in horticulture. Acta Hort. 26:37-44.

de Lima, R., F. de Assis Figueiredo, A. Martins, B. de Deus, T. Ferraz, M. Gomes, E.F. de Sousa, D. Glenn, and E. Campostrini. 2015. Partial rootzone drying (PRD) and regulated deficit irrigation (RDI) effects on stomatal conductance, growth, photosynthetic capacity, and water-use efficiency of papaya. Scientia Hort. 183:13-22.

de Oliveira Reis, F., E. Campostrini, E.F. de Sousa, and M.G. Silva. 2006. Sap flow in papaya plants: Laboratory calibrations and relationships with gas exchanges under field conditions. Scientia Hort. 110:254-259.

Dumroese, R.K. and R.L. James. 2005. Root diseases in bareroot and container nurseries of the Pacific Northwest: Epidemiology, management, and effects on outplanting performance. New For. 30:185-202.

Ferraz, T.M., A.T. Netto, F. de Oliveira Reis, A.L. Peçanha, E.F. de Sousa, J.A.M. Filho, W.P. Rodrigues, D.M. Glenn, and E. Campostrini. 2015. Relationships between sap-flow measurements, whole-canopy transpiration and reference evapotranspiration in field-grown papaya (Carica papaya L.). Theor. Exp. Plant Physiol. 27:251-262.

Flörke, M., C. Schneider, and R.I. McDonald. 2018. Water competition between cities and agriculture driven by climate change and urban growth. Nat. Sustain. 1:51-58.
Fulcher, A.F., J.W. Buxton, and R.L. Geneve. 2012. Developing a physiological-based, ondemand irrigation system for container production. Sci Hort. (Amsterdam) 138:221-226.

Granier, A. 1987. Evaluation of transpiration in a Douglas-fir stand by means of sap flow measurements. Tree Physiol. 3:309-320.

Guo, Y., T. Starman, and C. Hall. 2018. Reducing substrate moisture content during greenhouse production of poinsettia improves postproduction quality and economic value. HortScience 53:1618-1628.

Han, M., H. Zhang, K.C. DeJonge, L.H. Comas, and S. Gleason. 2018. Comparison of three crop water stress index models with sap flow measurements in maize. Agr. Water Mgt 203:366-375.

Hargreaves, G.H. and R.G. Allen. 2003. History and evaluation of Hargreaves evapotranspiration equation. J. Irrig. Drain. Eng. 129:53-63.

Hoekstra, A.Y. and A.K. Chapagain. 2008. Globalization of water: Sharing the planet's freshwater resources. Blackwell, Malden, MA.

Hoekstra, A.Y., M.M. Mekonnen, A.K. Chapagain, R.E. Mathews, and B.D. Richter. 2012. Global monthly water scarcity: Blue water footprints versus blue water availability. PLoS One 7:e32688.

Idso, S.B., R.D. Jackson, P.J. Pinter, R.J. Reginato, and J.L. Hatfield. 1981. Normalizing the stressdegree-day parameter for environmental variability. Agr. Water Mgt. 4:45-55.

Ingram, D.L., C.R. Hall, and J. Knight. 2016 Carbon footprint and variable costs of production components for a container-grown evergreen shrub using life cycle assessment: An east coast U.S. model. HortScience 51:989994

Jackson, R.D., W.P. Kustas, and B.J. Choudhury. 1988. A reexamination of the crop water stress index. Irrig. Sci. 9:309-317.

Jones, H.G. 2004. Irrigation scheduling: advantages and pitfalls of plant-based methods. J. Exp. Bot. 55:2427-2436.

Kiehl, P.A., J.H. Lieth, and D.W. Burger. 1992. Growth response of chrysanthemum to various container medium moisture tension levels. J. Amer. Soc. Hort. Sci. 117:224-229.

Kim, S.-H., J.H. Jeong, and L.L. Nackley. 2013. Photosynthetic and transpiration responses to light, $\mathrm{CO}_{2}$, temperature, and leaf senescence in garlic: Analysis and modeling. J. Amer. Soc. Hort. Sci. 138:149-156.

Letey, J. 2007. Optimizing irrigation for agricultural water management: Scientific principles. In: National Research Council (ed.). Agricultural water management: Proceedings of a workshop in Tunisia. The National Academies Press, Washington, DC

Levin, A.D. 2019. Re-evaluating pressure chamber methods of water status determination in fieldgrown grapevine (Vitis spp.). Agr. Water Mgt. 221:422-429.

Lichtenberg, E., J. Majsztrik, and M. Saavoss. 2014. Grower demand for sensor-controlled irrigation. Water Resour. Res. 51:341-358.

Lousada, L., E.F. de Sousa, and E. Campostrini. 2015. Advanced techniques using the plant as an indicator of irrigation management. Cienc. Rural 45:821-827.

Luo, Y., X. Chang, S. Peng, S. Khan, W. Wang, Q. Zheng, and X. Cai. 2014. Short-term forecasting of daily reference evapotranspiration using the Hargreaves-Samani model and temperature forecasts. Agr. Water Mgt. 136:42-51.

Majsztrik, J.C. and J.D. Lea-Cox. 2013. Water quality regulations in the Chesapeake Bay: Working to more precisely estimate nutrient loading rates and incentivize best management practices in the nursery and greenhouse industry. HortScience 48:1097-1102.

Majsztrik, J., E. Lichtenberg, and M. Saavoss. 2013. Ornamental grower perceptions of wireless irrigation sensor networks: Results from a national survey. HortTechnology 23:775-782.

Marin, F.R., L.R. Angelocci, D.S.P. Nassif, L.G. Costa, M.S. Vianna, and K.S. Carvalho. 2016. Crop coefficient changes with reference evapotranspiration for highly canopy-atmosphere coupled crops. Agr. Water Mgt. 163:139-145.

Marshall, D.C. 1958. Measurement of sap flow by heat transfer. Nature 182:878-879.

McDowell, N., W.T. Pockman, C.D. Allen, D.D. Breshears, N. Cobb, T. Kolb, J. Plaut, J. Sperry, A. West, D.G. Williams, and E.A. Yepez. 2008. Mechanisms of plant survival and mortality during drought: Why do some plants survive while others succumb to drought? New Phytol. 178:719-739.

Miralles-Crespo, J. and M.W. van Iersel. 2011. A calibrated time-domain transmissometry soil moisture sensor can be used for precise automated irrigation of container-grown plants. HortScience 46:889-894.

Morvant, J.K., J.M. Dole, and J.C. Cole. 1998. Irrigation frequency and system affect poinsettia growth, water use, and runoff. HortScience $33: 42-46$.

Nackley, L.L. 2019. Sap-flow sensors for smalldiameter nursery seedlings. Tree Plant. Notes 62. 29 June 2020 . <https://rngr.net/publications/ tpn/62-1-2/sap-flow-sensors-for-small-diameternursery-seedlings $>$.

Nackley, L.L., K.A. Vogt, and S.-H. Kim. 2014. Arundo donax water use and photosynthetic responses to drought and elevated $\mathrm{CO}_{2}$. Agr. Water Mgt. 136:13-22.

Nadezhdina, N. 1999. Sap flow index as an indicator of plant water status. Tree Physiol. 19:885-891.

Nambuthiri, S., E. Hagen, A. Fulcher, and R. Geneve. 2017. Evaluating a physiologicalbased, on-demand irrigation system for container-grown woody plants with different water requirements. HortScience 52:251-257.

Nemali, K.S. and M.W. van Iersel. 2008. Physiological responses to different substrate water contents: Screening for high water-use efficiency in bedding plants. J. Amer. Soc. Hort. Sci. 133:333-340.

Niu, G., D.S. Rodriguez, and Y.T. Wang. 2006. Impact of drought and temperature on growth and leaf gas exchange of six bedding plant species under greenhouse conditions. HortScience 41:1408-1411.

Oki, L.R., J.H. Lieth, and S. Tjosvold. 2001. Irrigation of Rosa hybrida L. 'Kardinal' based on soil moisture tension increases productivity and flower quality. Acta Hort 547:213-219.

Pershey, N.A., B.M. Cregg, J.A. Andresen, and R.T. Fernandez. 2015. Irrigating based on daily water use reduces nursery runoff volume and nutrient load without reducing growth of four conifers. HortScience 50:1553-1561.

Pitton, B.J., C.R. Hall, D.L. Haver, S.A. White, and L.R. Oki. 2018. A cost analysis for using recycled irrigation runoff water in container nursery production: A Southern California nursery case study. Irrig. Sci. 36:217-226.

Raziei, T. and L.S. Pereira. 2013. Estimation of ETo with Hargreaves-Samani and FAO-PM temperature methods for a wide range of climates in Iran. Agr. Water Mgt. 121:1-18.

R Development Core Team. 2013. R: A language and environment for statistical computing. $\mathrm{R}$ Foundation for Statistical Computing, Vienna, Austria. <https://www.R-project.org/>. 
Redekar, N.R., J.L. Eberhart, and J.L. Parke. 2019 Diversity of Phytophthora, Pythium, and Phytopythium species in recycled irrigation water in a container nursery. Phytobiomes J. 3:31-45.

Samani, Z. 2000. Estimating solar radiation and evapotranspiration using minimum climatological data. J. Irrig. Drain. Eng. 126:265-267.

Scagel, C.F., G. Bi, L.H. Fuchigami, and R.P. Regan. 2012. Irrigation frequency alters nutrient uptake in container-grown rhododendron plants grown with different rates of nitrogen. HortScience 47:189-197.

Schuch, U., R.A. Redak, and J. Bethke. 1996. Whole-plant response of six poinsettia cultivars to three fertilizer and two irrigation regimes. J. Amer. Soc. Hort. Sci. 121:69-76.

Shackel, K., H. Ahmadi, W. Biasi, R. Buchner, D. Goldhamer, S. Gurusinghe, J. Hasey, D. Kester, B. Krueger, B. Lampinen, G. McGourty, W. Micke, E. Mitcham, B. Olson, K. Pelletrau, H. Philips, D. Ramos, L. Schwank1, S. Sibbett, R. Snyder, S. Southwick, M. Stevenson, M. Thorpe, S. Weinbaum, and J. Yeager. 1997. Plant water status as an index of irrigation need in deciduous fruit trees. HortTechnology 7:23-29.
Skelton, R.P., A.G. West, and T.E. Dawson. 2015. Predicting plant vulnerability to drought in biodiverse regions using functional traits. Proc. Natl. Acad. Sci. USA 112:5744-5749.

Testi, L., D.A. Goldhamer, F. Iniesta, and M. Salinas. 2008. Crop water stress index is a sensitive water stress indicator in pistachio trees. Irrig. Sci. 26:395-405.

U.S. Department of Agriculture. 2019. National Agricultural Statistics Service-Floriculture crops 2018 summary. 29 June 2020. <https:// www.nass.usda.gov/Publications/Todays Reports/reports/floran19.pdf $>$.

Warner, L.A., A.J. Lamm, P. Beattie, S.A. White, and P.R. Fisher. 2018. Identifying opportunities to promote water conservation practices among nursery and greenhouse growers. HortScience 53:958-962.

Warren, S.L. and T.E. Bilderback. 2005. More plant per gallon: Getting more out of your water. HortTechnology 15:14-18.

Weiland, J.E., C.F. Scagel, N.J. Grünwald, E.A. Davis, B.R. Beck, and V.J. Fieland. 2018 Variation in disease severity caused by $P h y$ tophthora cinnamomi, $P$. plurivora, and
Pythium cryptoirregulare on two rhododendron cultivars. Plant Dis. 102:2560-2570.

Welsh, D. and J. Zajicek. 1993. A model for irrigation scheduling in container-grown nursery crops utilizing management allowed deficit (MAD). J. Environ. Hort. 11:115-118.

Wheeler, W., R. Wytsalucy, B. Black, G. Cardon, and B. Bugbee. 2019. Drought tolerance of Navajo and Lovell peach trees: Precision water stress using automated weighing lysimeters. HortScience 54:799-803.

White, S.A. 2013. Wetland technologies for nursery and greenhouse compliance with nutrient regulations. HortScience 48:1103-1108.

Wilson, C., J. Albano, M. Mozdzen, and C. Riiska. 2010. Irrigation water and nitrate-nitrogen loss characterization in southern Florida nurseries: Cumulative volumes, runoff rates, nitratenitrogen concentrations and loadings, and implications for management. HortTechnology 20:325-330.

Yeager, T., J. Million, C. Larsen, and B. Stamps. 2010. Florida nursery best management practices: Past, present, and future. HortTechnology 20:82-87. 